\title{
학교폭력예방 학급환경 진단도구 개발
}

\author{
이숙정 (李淑貞)* \\ 박소연(朴昭咑) ${ }^{* *}$ \\ 이희현(李喜鉉) ${ }^{\star \star \star}$ \\ 유지현(俞知賢) ${ }^{* * * *}$
}

\section{논문 요약}

본 연구는 학교폭력 예방을 위한 학급환경 진단도구를 개발하는 데 그 목적이 있다. 이를 위하여 학급환경과 학교폭력에 대한 선행연구들을 검토하여 학급환경 관련 측정문항들을 개발하고 예비문항들에 대한 전문가의 내 용타당도 검증을 실시하였다. 44 개의 예비문항으로 구성된 학급풍토 진단도구가 타당한지 검증하기 위해서 서 울, 경기, 충청지역의 초등학교 5 학년과 6 학년, 중학교 1 학년과 2 학년 학생들 293 명을 대상으로 예비검사를 실 시하고, 396명을 대상으로 본 검사를 실시하였다. 수집된 자료의 탐색적, 확인적 요인분석 결과, 또래지지, 또래 -학급폭력허용, 교사지지, 교사-학급폭력허용, 학급규칙, 학급응집성 등 6개 요인으로 구성된 총 34문항의 학 급환경 진단도구를 개발하였다. 준거타당도 검증을 통해 학급환경 진단도구는 사용 가능한 유의한 척도임을 확 인하였다. 본 연구결과를 기초로 학급환경 진단도구 개발의 의의와 시사점을 논의하였다.

주요어 : 학급환경, 학교폭력, 폭력예방, 진단도구 개발

* 제1저자, 숙명여자대학교 리더십교양교육원 부교수, leesjeong@sm.ac.kr

** 교신저자, 숙명여자대학교 리더십교양교육원 겸임교수, psychitest@naver.com

*** 한국교육개발원 학교폭력예방연구지원특임센터 연구위원, hyun@kedi.re.kr

**** 선문대학교 교수학습혁신센터 조교수, edupsy0502@sunmoon.ac.kr 


\section{I. 서론}

최근 초등 및 중등학교를 중심으로 청소년들의 학교폭력이 증가하고 있으며, 이에 따라 학교 폭력의 원인과 대책에 대한 관심도 높아지고 있다. 우리나라에서 학교폭력은 폭력행위의 일종으 로서 폭력이 일어나는 장소가 학교이기 때문에 학교폭력이라고 보는 견해가 많으며 학교폭력과 관련된 용어로 집단따돌림, 집단 괴롭힘, 또래 괴롭힘, 왕따 등의 용어가 혼용되어 사용되고 있 다(이승하, 2012).1)

학교폭력은 주로 학교 안팎에서 또래폭력으로 나타나는데, 최근에는 학교폭력에 노출되는 시 기가 점차 낮아지고 있어서 이에 대한 예방대책이 시급한 실정이다. 학교폭력 피해경험에 대한 교육부의 2014년 1차 실태조사에 따르면, 학급별로 초등학생 $(2.4 \%)$ 의 피해경험이 중학생 $(1.3 \%)$ 과 고등학생 $(0.6 \%)$ 의 피해경험에 비해 높았으며, 성별에 따른 피해는 남학생 $(1.6 \%)$ 이 여학생 $(1.1 \%)$ 에 비해 학교폭력 피해경험이 높은 것으로 나타났다(교육부, 2014).

또한 학교폭력은 다양한 형태로 나타나기 때문에 단순한 피해경험의 비율 뿐 아니라, 학교구 성원들이 학교폭력에 대해 어떻게 인식하는지, 어떤 유형의 학교폭력이 더 심각한지에 대한 고 려도 필요하다. 한국청소년정책연구원(2012)의 조사에 따르면, 중학교 교사가 학교폭력을 가장 심각하게 인식하는 것으로 나타났으며, 초등학교에서는 비물리적인 유형이, 중·고등학교에서는 물리적인 유형의 학교폭력이 보다 우세하다고 교사들이 인식하고 있었다. 또한 학교폭력을 줄이 기 위한 바람직한 학교문화에 대해 교사들은 학생, 교사, 학부모가 상호협력하고 배려하는 공동 체적 학교문화 조성 $(61.0 \%)$ 을 가장 중요하게 생각하고 있으며, 교사들은 학생, 교사, 학부모의 소통이 원활해지고 관계가 개선되면 학교폭력이 줄어들 것(88.5\%)으로 생각하여 학교 구성원들 간의 관계 개선과 의사소통의 중요성을 심각하게 인식하고 있는 것으로 나타났다(윤경철, 강명 숙, 2012).

학교폭력이 학생들 간에 이루어지는 것이기는 하지만, 학생들의 개인적 배경과 심리사회적 특성, 학교 및 학급환경, 사회적 배경 등이 총체적으로 영향을 주고 있기 때문에, 생태학적 관점 에서 학교폭력에 영향을 미치는 요인들을 파악하는 접근이 가장 포괄적으로 인식되고 있다. 일 반적으로 생태학적 관점에서는 학교폭력에 영향을 미치는 요인을 크게 개인적 요인과 환경적 요인으로 구분한다. 개인적 요인은 성별과 충동성, 공격성 등이 포함되며, 환경적 요인은 청소년

1) 학교폭력에 대한 법적인 정의는 “학교폭력예방 및 대책에 관한 법률"(2013.7.30.) 제2조 1호에 따르면, 학교 폭력은 '학교 안이나 밖에서 학생 사이에 발생한 상해, 폭행, 감금, 협박, 약취, 유인, 명예훼손, 모욕, 공갈, 강요 및 성폭력, 따돌림, 정보통신망을 이용한 음란, 폭력 정보 등에 의하여 신체, 정신 또는 재산의 피해 를 수반하는 행위'를 말한다.

http://www.lawnb.com/lawinfo/link_view.asp?cid=86726D6D84B1499490D1B1B3B19D2B5B | L,검색일, 2014.9.30) 
과 가장 밀접한 미시체계인 가족, 학교, 지역사회, 문화변인으로 구분하여 분석하고 있다(황혜 원, 신정이, 박현순, 2006; Orpinas \& Horne, 2006). 특히 생태학적 모형은 학교에서의 폭력을 예방하는데 있어서 중요하게 고려해야 할 관점으로 알려져 있는데, 왜냐하면 학교폭력이 학교라 는 다수의 학생들이 함께 생활하는 공간 속에서 이루어지며, 학급집단의 영향력이 가해학생들의 의식의 저변에 자리 잡고 있기 때문이다(장명배, 2008).

이러한 관점에 따라, 학교폭력의 원인과 대책에 관한 선행연구들(김미영, 2007; 김은영, 2008; 박영신, 김의철, 2001; 이상균, 1999; 황혜원, 신정이, 박현순, 2006; Guerra, Williams, \& Sadek, 2011; Kasen, Berenson, Cohen \& Johnson, 2004; Pozzoli, Gini, \& Vieno, 2012)은 개인을 둘러싼 환경적 요인에 관심을 두고 있으며, 그 중에서도 학급이나 학교수준에 초점을 두고 연구를 진행 하고 있다. 왜냐하면, 학생들 개개인의 특성과 관련된 개인적 요인들은 경우의 수가 다양하고 교사나 학교의 노력으로 단기간에 많은 학생들을 대상으로 학교폭력을 감소시키는 효과를 기대 하기가 현실적으로 어렵기 때문이다. 현실적으로도 또래변인, 교사변인, 학급집단의 특성, 학급 분위기, 학급응집력 등의 요인에 관심을 두고 그 개선점을 강화하는 것이 학급에서 발생하는 학 교폭력 예방효과를 모색하는데 도움이 될 수 있다.

최근에 국내에서 이루어진 연구들을 살펴보면, 학교분위기(김은영, 2008), 학교체계(김미영, 2007), 학교환경(이상균, 2005), 학교변인(박종효, 2013; 황혜원, 신정이, 박현순, 2006), 학교유대 감(오인수, 이승연, 이주연, 2013), 사회적지지(한남식, 어주경, 2012) 등의 변인을 사용하여 학교 폭력과의 연관성을 분석하고 있다. 국외연구에서도 학교관련 변수들 중 교사와 학생 간 상호작 용, 교칙의 명료성과 학교정책의 일관성, 학생들의 의사결정 참여기회, 학교 내 폭력적 환경 유 무 등을 포함시킨 학교분위기에 초점을 두고 또래폭력에 대한 연구들(Benbensishty, et al., 2002;

Furlong \& Morrison, 2000; Hyman \& Perone, 1998; Olweus, 1994; Yablon, 2012)이 진행되고 있다.

학교환경은 학생들이 지각하는 학교분위기로써 심리사회적 학교환경을 의미하며, 연구자들 (Furlong et al., 2005; Ryan \& Patrick, 2001)은 학교환경에 대한 주요 접근이 주로 교사, 학생 등 학교 구성원들이 지각한 학교분위기에 초점을 두어야 한다고 제안하고 있다. 그러나 Trickett 과 $\operatorname{Moos}(1973)$ 는 좀 더 시야를 좁혀서 학교환경을 결정하는 기초가 학급환경(class environment)이며, 학급환경은 교사의 행동과 교사-학생, 학생-학생 간의 상호작용을 포함하는 역동적인 사회체계라고 개념화하였다. 국내연구에서도 학교건물의 유지보수, 학교의 위치 등을 포함하는 물리적 환경보다는 또래집단, 교사와의 관계, 학급분위기에 초점을 둔 보다 미시적 관 점의 학급환경에 초점을 둔 연구들이 수행되고 있다. 이와 같이 학급환경을 주로 학급 내 심리적 변인들의 특성으로 보는 가장 큰 이유는 학급 내 교사와 학생의 관계, 또래들 간의 관계 등이 학교에서 일어나는 학교폭력의 주된 원인 중 하나라는 점(김순혜, 2012; 오인수, 이승연, 이주연, 
2013)과 물리적 환경에 비해 상대적으로 교육적 개입이 적극적으로 이루어질 수 있기 때문이다. Trickett과 Moos(1973)도 학급환경은 학교 안에서의 공식적인 최소집단인 학급을 기본 단위로 하기 때문에, 학급 구성원들 간의 직접적인 상호작용을 구체적으로 파악할 수 있다는 장점이 있 으며, 전반적인 학교환경과는 다소 차이가 있다고 제안하고 있다.

따라서, 학교폭력의 예방과 대책을 위해서는 학교환경 뿐 아니라 학급분위기, 학급풍토, 학급 문화 등의 학급환경에 초점을 둔 진단과 분석이 필요하다. 그런데, 국내에서 수행된 최근의 관련 연구들을 검토해 보면, 다양한 용어로 혼용되고 있기는 하지만, 학교환경을 진단하기 위해서 사 용되는 척도들이 매우 제한적임을 확인할 수 있다. 학교환경 척도를 변형하여 학급환경 진단에 적용하는 경우도 있고, 국외에서 개발한 척도를 번안하여 사용하기도 한다. 예컨대, 학교환경의 측정에 주로 사용되고 있는 척도들은 국외에서 개발된 척도를 국내 상황에 맞게 또는 연구목적 에 맞게 수정, 보완하여 사용하는 것으로 Benbensishty, Astor, Zeira와 Vinokur(2002)의 학교분 위기 척도, 이점형(2013)이 Fraser, Anderson과 Walberg(1982)이 개정한 MCI(My Class Inventory)를 수정·번안한 학교분위기 척도, Schmuck과 Schmuck(1992)의 학급풍토척도, Furlong 둥(2005)이 사용한 캘리포니아 학교풍토 및 안전척도(California School Climate and Safety Survey: CSCSS), Rutter 등(1979)과 Gottfredson 등(2005)의 학교환경척도, Dubow와 Ullman(1989)의 사회적지지 평가(SSAS) 척도, California Healthy Kids Survey에서 활용하고 있 는 The School Connectedness Scale의 5 문항 버전(You et al., 2008) 학교유대감 척도 등이 최근 의 연구에서 자주 사용되고 있는 척도들이다.

이와 같이 학급환경에만 초점을 둔 도구는 찾아보기 힘들며, 측정하고자 하는 범위와 내용이 매우 광범위하고 여러 개의 도구들을 혼합하여 수정하거나, 연구자에 의해 다양하게 수정된 도구 들이 대부분이어서, 학교폭력 예방 차원에서 학급환경을 진단 및 분석하고 이러한 연구결과들을 총합하여 대책 및 대안을 제시하는데 한계가 있다. 따라서 본 연구에서는 학교폭력 예방을 위한 생태체계학적 접근 중 학생과 매우 밀접한 미시체계인 학급에 초점을 두고 국내외 선행연구 검토 결과를 토대로 하여 학교폭력 예방을 위해 학급환경을 진단할 수 있는 도구를 개발하고자 한다.

\section{ㅍ. 이론적 배경}

\section{1. 학급환경의 특성}

학급은 집단의 형태를 유지하고 하나의 작은 사회를 구성하며, 학교는 아동과 청소년에게 가 장 안전한 공적 환경이다(Hyman \& Perone, 1998). 이러한 집단이 지녀야 할 특성으로 박성희 
(2005), 강진령(2011)은 구성원들 간의 직접적인 의사소통과 유의한 상호작용을 바탕으로 역동적 상호관계를 이뤄야 하고 생산적인 방식으로 상호 의존해야 한다고 보았으며, Forsyth(2001)도 구성원들 간의 상호작용과 집단의 구조 및 응집성과 정체성을 강조하였다(이정윤, 2014 재인용). 따라서 학급집단이 원활하게 작동하기 위해서는 특히 담임교사의 역할이 매우 중요하다고 볼 수 있는데, 학급환경은 학교환경을 결정하는 기초가 되기 때문이다(Trickett \& Moos, 1973).

학급환경은 교사의 행동과 교사-학생, 학생-학생 간의 상호작용을 포함하는 역동적인 사회체 계로서 학급 구성원들이 공유하고 있는 학급환경에 대한 지각이라고 볼 수 있다(이은정, 1997). 따라서 학급에서 이루어지는 교사와 학생, 학생과 학생 간의 상호작용의 특성, 학급 분위기, 담 임교사의 학급운영 철학과 규칙 등은 학급 구성원들이 학급환경을 어떻게 지각하는가에 영향을 줄 수 있다. 일반적으로 학교에서의 폭력은 학교환경과 연계되어 있을 가능성이 높다고 알려져 있으며, 교사와의 관계, 또래와의 관계, 학급 분위기 등의 학교체계가 생태체계적 관점에서 중요 한 변인으로 간주되고 있다(김미영, 2007; 도기봉 2007; 황혜원, 신정이, 박현순, 2006; Orpinas \& Horne, 2006).

따라서 학교폭력의 예방을 위해서는 생태체계의 각 차원별 위험요인(risk factor)과 보호요인 (protective factor)을 파악하여 위험요인을 줄이고 보호요인을 강화해 나가는 접근을 시도하는 것이 필요하다. Orpinas와 Horne(2006)은 학교환경과 관련한 위험요인으로 학교의 부정적 풍토, 교사와 학생간의 긍정적 관계의 부족, 학교의 관리감독의 부재, 교사의 학생 괴롭힘 허용, 학교 의 처벌 시스템(무관용 정책)을 제안하고 있다. 관련 선행연구들은(이상균, 1999; Dwyer, Osher \& Hoffman, 2000)은 또래폭력에 영향을 미치는 요인 중 개인적 변수와 더불어 학교관련 변수가 가장 중요한 변수라고 지적하고 있다. 학교생활에서 실패했다는 사실은 10 대 학생들의 비행과 폭력, 그리고 성인폭력에 대해서 강력한 예측변수가 된다(Orpinas \& Horne, 2006). 또한 학교생 활은 학업성취와 관련된 부분을 포함하여 교사와 또래관계에서 부정적 피드백의 경험, 낮은 지 지 등 심리사회적 변수들이 함께 영향을 미치게 된다. 물론 개인의 생물학적, 심리적 특성들도 폭력을 유발하는 위험요인이 될 수 있다. 그러나 더 중요한 것은 폭력적인 행동결과에 대한 보상 을 기대할 수 있을 때, 그리고 폭력과 보상에 대한 반복적인 경험이 축적될 때 폭력이 더 증가하 게 된다는 것이다. 학생들에 대한 교사와 학교의 관리 소홀도 위험요인으로 작용할 수 있는데, 교사가 교실에서 일어나는 폭력적 행동을 무시하거나 원칙을 공정하게 적용하지 않거나 문제 학생들을 불신하거나 싫어하는 모습을 보이게 되면 부정적인 학급환경을 형성하게 된다(김준호, 박정선, 김은경, 1996; Orpinas \& Horne, 2006). 이와 같이 학교폭력 위험요인 중 학급환경의 변 인들을 살펴보면, 학생 간, 교사와 학생 간 등 학급내 부정적인 관계, 폭력허용도, 학급규칙 등 학급 내 심리적 변인, 학교폭력에 대한 태도, 부정적인 학급분위기 등 다양하다. 개인적 성향을 조절하고 통제할 수 있는 환경 변인으로써 위험요인을 인지하고 이러한 위험요인이 발생할 때 
적극적으로 개입하여 감소시키거나 제거하는 것이 중요하다고 볼 수 있다.

한편, 학교폭력을 예방하기 위한 중요한 요인으로 보호요인을 들 수 있다. 일반적으로 긍정적 학급풍토, 교사와 학생 간 긍정적 관계, 교사의 관심, 높은 수준의 관리감독, 분명한 괴롭힘 예방 정책, 훌륭한 수업 장려, 학습지원이 필요한 학생들에게 기회 제공, 학교활동에 적극적 참여 기 회, 모든 학생에 대한 높은 기대 등이 보호요인으로 제시되고 있다(Orpinas \& Horne, 2006). 특 히 많은 선행연구들(김은영, 2008; 도기봉, 2007; 박주형, 정성수, 2012; 이은희, 공수자, 이정숙, 2004; 이상균, 2005; 신성자, 2005; Astor, Meyer, \& Behre, 1999; Benbenishty, Astor, Zeira, \& Vinokur, 2002)은 교사의 관심과 개입을 학교폭력을 중재하거나 예방할 수 있는 중요한 보호요 인으로 제시하고 있다. 이러한 연구들은 공통적으로 교사가 학교폭력에 대하여 묵인하거나 적절 히 개입하지 못하고 미온적인 태도를 보일 때에는 이것이 암묵적인 지지와 승인의 의미를 지니 게 되어 학교폭력의 증가요인이 되며, 반대로 교사가 민감하게 인식하여 신속하고 적극적으로 대처할 경우, 학교폭력이 상당히 줄어들 수 있다고 강조하고 있다.

박성희(2005)는 학급의 지도자로서 교사의 역할에 대해, 학급 일들에 대해 상세하고 다양한 정보를 갖고 있어야 하며, 공감과 경청을 수반한 좋은 의사소통의 기술을 갖고 학급의 구조의 체계를 세우고 유지할 수 있어야 하며, 민주적 리더십을 가지고 합리적이고 촉진적인 분위기를 조성하고 학생들이 자율적으로 행동하고 책임을 질 수 있는 분위기를 조성해야 하고 학급의 응 집력을 향상시키기 위해 노력해야 하고 학급에서의 갈등이 발생할 경우 이를 신속하고 원만하 게 관리할 수 있어야 한다고 보고 있다. 또한 Ryan과 Patrick(2001), Hein(2004)도 중학교 교사와 학생의 관계 연구를 통하여 학생들의 행동을 개선하여 긍정적인 학급환경을 만드는데 가장 중 요한 것은 교사의 지지를 통하여 학생 스스로 존중받고 보호받고 있다고 느끼도록 해주는 것이 라고 밝히고 있다. 그 밖에도 긍정적인 학급환경과 학교풍토(환경, 분위기)는 학교폭력을 줄이는 데 유의한 영향을 준다고 보고하고 있다(김경집, 2005; 남영옥, 한상철, 2007; 도기봉, 2007; 황혜 원, 신정이, 박현순, 2006; Kasen, Cohen \& Brooks, 1998; Orpinas \& Horne, 2006).

이와 같이, 학교폭력의 보호요인은 학교폭력을 유발하는 위험요인의 부정적인 영향을 중재하 거나 완화시키는 작용을 통해 학교폭력을 예방하는데 중요한 역할을 한다. 특히, 학급환경으로 서의 보호요인을 규명하는 것은 학교폭력이 발생하는 학급차원의 폭력을 예방하고, 학교폭력을 예방하기 위한 학급환경 조성하는데 기본적인 정보를 제공하게 될 것이다.

\section{2. 학급환경 구성요인}

최근 학교폭력을 예방하기 위한 학급환경의 보호요인으로 또래지지와 교사지지 등 사회적지 지가 강조되고 있다(오인수, 이승연, 이주연, 2013). 우선, 또래지지는 학교폭력의 보호요인으로 
작용하며(김순혜, 2012; 성지희, 정문자, 2007), 또래 괴롭힘 피해와 부적 상관이 있는 것으로 밝 혀졌다(김미경, 강문희, 2006; 이혜경, 김혜원, 2001; 한남식, 어주경, 2012; Rigby, 2000). 또한 교 사와의 관계가 우호적이고 지지적일수록 학생들이 학교에 적응을 잘하고(황혜원, 신정이, 박현 순, 2006), 교사와 학생간의 정서적 유대감이 형성되고 지지적인 관계를 가질 때 학교폭력 예방 은 물론 학교폭력 대처에도 긍정적 영향을 미치는 것으로 나타났다(김은영, 2008; 신성자, 권신 영, 2013). 장미향과 성한기(2007)는 교사지지를 낮게 지각하는 학생일수록 학교폭력 피해경험이 많은 것을 밝힌바 있다. 즉, 교사지지가 학교폭력의 보호요인으로 작용하는 것이다(김순혜, 2012; 남영옥, 한상철, 2007; 박영신, 김의철, 2001; 성지희, 정문자, 2007; Orpinas \& Horne, 2006).

한편, 김경집(2005)은 또래폭력에 영향을 미치는 학교환경요인으로 폭력문화의 허용도를 강조 하였다. 특히, 교사를 포함한 학생들이 학교 내에서 폭력에 대해 허용적이고 동조적인 분위기를 보이는 환경인 경우에는 학생 스스로가 폭력에 대해 부정적인 태도 및 가치를 가지더라도 폭력 에 가담하게 된다. 정진성(2009)도 학교폭력의 원인에 대한 연구에서 폭력의 문화적 용인을 학교 수준의 주요 요인으로 보았으며 교사와 학생들이 폭력에 무관심하고 폭력에 대해 용인하는 정 도가 클수록 폭력을 많이 행사할 것이라고 가정한 바 있다. 즉, 또래 폭력허용도와 교사 폭력허 용도는 학교폭력에 영향을 미치는 주요 심리사회적 환경인 것이다. 또래 폭력허용도와 학교 폭 력과의 관계에 대한 연구들(김미영, 2007; 김순혜, 2006; 정규석, 2006; 최운선, 2005)은 또래 폭력 허용도가 높은 환경에서 학교폭력에 더 많이 노출되는 것을 밝힌바 있다. 특히 최운선(2005)은 학교폭력에 영향을 미치는 요인에 대한 메타분석을 통해 학교폭력 가해경험에 가장 큰 영향을 미치는 요인이 또래 폭력허용도임을 제안하였다. 또한 교사의 학교폭력에 대한 무관심은 학교폭 력에 영향을 미치는 요인이며(Harootunuan \& Apter, 1993, 김미영, 2007 재인용), 교사가 학교 폭력에 대해 방임적인 경우, 학교폭력이 증가하게 된다(이은정, 2003, 도기봉 2008 재인용). 즉, 또래와 교사가 폭력에 대한 문제의식과 관심을 가지고 폭력행위에 대해 허용하지 않는 태도를 가지는 것이 학교폭력을 예방하기 위한 요인으로 작용하는 것이다.

학교폭력을 예방하기 위한 생태체계적 접근에서는 학교폭력의 원인으로 학교 및 학급체계를 포함하고(김미영, 2007; 김은영, 2008; 이상균, 1999; Orpinas \& Horne, 2006), 학교폭력에 영향을 미치는 학급의 분위기 및 환경요인으로 교칙의 명료성 및 공정성과 학급응집성을 강조한다. 학 생이 지각하는 교칙의 명료성과 공정성은 학교폭력에 영향을 미치는 요인이며(김은영, 2008; 이 상균, 1999; 박주형, 정성수, 2012; Benbenishty et al., 2002), 특히 박주형과 정성수(2012)는 학교 폭력에 영향을 미치는 학교의 영향요인 분석을 통해 학생들이 인식하는 학교규칙의 명료성과 공정성 여부가 높을수록 학교폭력이 발생할 확률이 낮은 것을 확인한 바 있다. 오인수(2010)는 집단따돌림을 예방하기 위한 학급차원의 접근으로 학급원의 참여를 통한 따돌림 관련 학급규칙 의 제정 및 일관적인 시행을 강조하고 있다. 또한 학급응집성도 학교폭력에 영향을 미치는 요인 
으로 밝혀졌다(김미영, 2007; 황혜원, 신정이, 박현순, 2006). 학급응집성은 학급구성원이 학급집 단에 대해 갖는 모든 감정과 느낌으로 개인과 개인이 아닌 개인과 학급집단 전체와의 관계를 강조한다(Schmuck \& Schmuck, 1992). 따라서 학급응집성은 학생과 학생, 학생과 교사간의 관계 가 아닌 학생과 교사를 포함한 학급구성원 전체 간의 소속감과 일체감을 의미하며, 학급응집력 이 낮으면 학급에서 이탈하는 학생이 생겨서 학급에 문제가 많아지고(김미영, 2007) 집단따돌림 및 폭력행위가 발생하게 된다(이훈구 등, 2000).

이상에서 살펴본 바와 같이, 학교폭력을 예방하기 위한 학급환경은 첫째, 사회적지지 즉, 또래 지지와 교사지지, 둘째, 학교폭력에 대한 태도, 셋째, 학급분위기, 규칙, 응집성 등의 학급문화 등으로 구분할 수 있다.

\section{III. 연구 방법}

\section{1. 연구대상}

학급환경 진단도구 개발을 위해서 서울 및 경기지역에 소재한 초등학교 5학년과 6학년 220명 과 중학교 1학년과 2학년을 대상으로 예비검사 및 본 검사를 실시하였다. 예비검사는 2014년 5월 셋째 주와 넷째 주에 실시하였으며, 본 검사는 2014년 7월 둘째 주부터 넷째 주까지 실시하였다. 수집된 자료 중 응답이 불성실하거나 미 수합된 설문지를 제외하고 예비검사는 293부, 본 검사는 396부가 최종 분석대상이 되었다. 구체적인 최종 분석대상의 표집 특성은 <표 $1>$ 과 같다.

<표 1> 표집 수

\begin{tabular}{ccccccc}
\hline & 성별 & 초등5학년 & 초등6학년 & 중등1학년 & 중등2학년 & 전체 \\
\hline \multirow{3}{*}{ 예비검사 } & 남학생 & 11 & 40 & 73 & 48 & 172 \\
\cline { 2 - 7 } & 여학생 & 13 & 30 & 56 & 22 & 121 \\
\cline { 2 - 7 } & 전체 & 24 & 70 & 129 & 70 & 293 \\
\hline \multirow{3}{*}{ 본 검사 } & 남학생 & 25 & 51 & 101 & 52 & 229 \\
\cline { 2 - 7 } & 여학생 & 13 & 37 & 79 & 38 & 167 \\
\cline { 2 - 7 } & 전체 & 38 & 88 & 180 & 90 & 396 \\
\hline
\end{tabular}




\section{2. 측정도구 및 분석절차}

개발된 학급환경 진단도구의 준거 타당도를 검증하기 위해서 학교폭력경험 척도를 활용하였 다. 학교폭력경험 척도는 교육부(2014)의 학교폭력 가·피해경험 척도와 이춘재와 곽금주(2000), 이수경과 오인수(2012)가 활용한 척도를 바탕으로 수정하였다. 본 척도는 가해경험과 피해경험 각각 8문항씩 총 16 문항으로 구성되어 있으며, 2014년 3월부터 한 학기동안의 가해 또는 피해경 험을 '전혀 없다' -0점, '지금까지 1 2번'-1점, '한 달에 1번 이하'-2점, '한 달에 2 3번 정도'-3점,'1 주일에 한 번 이상-4점으로 표시하게 되어 있다.

또한 개발된 학급환경 진단도구의 공인타당도를 검증하기 위해서 학급풍토, 사회적지지 등과 관련된 기존 도구들을 사용하였다. 공인타당도 검증을 위해서 상관분석을 실시하였다. 타당화 과정에서 사용된 학급풍토는 이점형(2013)이 Fraser, Anderson와 Walberg(1982)이 개정한 $\mathrm{MCI}(\mathrm{My}$ Class Inventory)를 수정·번안한 측정도구 중 8문항으로 구성된 갈등 척도와 6문항인 응집성 척도를 사용하였다. 이점형(2013)의 연구에서 제시한 Cronbach's $\alpha$ 계수는 갈등 척도가 .61 , 응집성 척도가 .84였으며, 본 연구에서 산출한 갈등 척도의 Cronbach's $\alpha$ 계수는 .89 , 응집 성 척도는 .88로 확인되었다. 사회적 지지는 오인수 등(2013)이 Dubow와 Ullman(1989)의 또래, 교사, 가족의 사회적 지지평가 척도(SSAS)를 번안한 척도 중 가족지지를 제외하고 또래지지 5 문 항과 교사지지 5문항을 사용하였다. 오인수 외(2013)의 연구에서 제시한 Cronbach's $\alpha$ 계수는 또래지지 척도가 .92, 교사지지 척도는 .81이었으며, 본 연구에서 산출한 Cronbach's $\alpha$ 계수는 또래지지 척도 .93 , 교사지지 척도.78로 확인되었다. 본 연구의 분석을 위해 사용한 통계 프로그 램은 PASW 18.0과 AMOS 5.0 이다.

\section{IV. 연구 결과}

\section{1. 문항제작 및 예비검사 분석}

학교폭력 예방을 위한 학급환경 진단도구를 개발을 위래서 수집한 자료 분석은 다음과 같은 과정으로 진행되었다. 첫째, 학급환경과 관련된 이론적, 경험적 선행연구들을 분석하였다. 우선 학교폭력과 관련된 선행연구들이 주로 사용한 학급환경 진단도구와 학급분위기, 학급풍토, 학급 환경 등 유사한 주제어를 갖고 있는 관련 도구들을 검토하였다. 선행연구(김경집, 2005; 김미영, 2007; 김순혜, 2006; 김은영, 2008; 오인수, 2010; 오인수, 이승연, 이주연, 2013; 이상균, 1999 등) 검토결과, 첫째, 또래 간의 친밀한 관계 형성에 대한 또래지지, 둘째, 또래들이 폭력에 대해 허용 
하고 용인하는 정도에 대한 또래폭력허용도, 셋째, 학생과 교사 간의 친밀한 관계 형성 및 신뢰 에 대한 교사지지, 넷째, 교사의 폭력에 대한 관심 및 허용정도에 대한 교사폭력허용도, 다섯째, 학교폭력에 대한 학급의 규칙 제정, 규칙의 명료성 및 규칙 적용의 공정성에 대한 학생들의 인식 과 관련한 학급규칙, 여섯째, 학급구성원간의 친밀감 및 일치성, 단결성에 대한 학급응집성으로 구성될 수 있다. 따라서 본 연구에서는 학교폭력을 예방하기 위한 학급환경의 영역을 또래, 교 사, 학급영역으로 구분하고 각각 또래관련 변인으로 또래지지, 또래폭력허용, 교사관련 변인으 로 교사지지, 교사폭력허용, 학급차원 변인으로 학급규칙, 학급응집성으로 구성하고자 한다.

선행연구에서는 국내에서 개발된 도구와 국외에서 개발된 진단도구 및 우리나라에서 번역하 여 사용되고 있는 도구들을 추출하여 비교 검토하여 교육심리학 교수 3 명, 학교폭력 전문가 1 명 등 교육학 전공 전문가들이 참여하여 예비문항을 제작하였다.

또래, 교사, 학급영역으로 구분하여 또래영역 중 또래지지 7 문항, 또래 학교폭력허용 8 문항, 교사영역 중 교사지지 7 문항, 교사 학교폭력허용 8 문항, 학급영역 중 학급규칙 7 문항, 학급응집 성 7 문항으로 총 44 문항을 개발하였다. 문항은 “전혀 그렇지 않다"에서 “매우 그렇다"까지의 5 점 Likert 척도로 구성하였다. 하위척도별 문항의 예는 <표 2>에 제시되어 있다.

<표 2> 예비문항의 하위척도와 문항 수

\begin{tabular}{|c|c|c|c|}
\hline 영역 & 하위척도 & 문항 수 & 문항 예 \\
\hline \multirow{2}{*}{ 또래 } & 또래지지 & 7 & 우리 반 친구들은 내 생각이나 말을 잘 들어준다. \\
\hline & 학급폭력허용 & 8 & 우리 반 친구들은 서로 놀리거나 헐뜯는다. \\
\hline \multirow[b]{2}{*}{ 교사 } & 교사지지 & 7 & 담임선생님께 내 고민을 털어놓고 이야기할 수 있다. \\
\hline & 학급폭력허용 & 8 & $\begin{array}{l}\text { 담임선생님은 우리 반에서 따돌림이나 괴롭힘이 있을 때, } \\
\text { 모른 체 하신다. }\end{array}$ \\
\hline \multirow{2}{*}{ 학급 } & 학급규칙 & 7 & 우리 반에서 발생한 문제들은 학급 규칙에 따라 처리된다. \\
\hline & 학급응집성 & 7 & 나는 우리 반에 속해 있는 것이 자랑스럽다. \\
\hline
\end{tabular}

총 문항 수

44

둘째, 개발된 예비문항들에 대한 예비검사를 실시하였다. 예비검사의 실시 목적은 개발한 문항 의 양호도를 확보하기 위한 것으로, 각 척도를 측정하는 신뢰로운 문항들을 선정하기 위해 실시 되었다. 예비문항의 분석결과, 평균, 표준편차, 왜도, 첨도 등을 확인하여 문항 반응의 편파성을 검토하였으며, 탐색적 요인분석을 통하여 해석할 수 있는 요인들을 선정하여 최종적인 척도 및 문항들을 선정하였다. 탐색적 요인분석에서 공통요인모형의 기초구조의 추출 방법으로 주성분분 석(principal factor analysis)을 사용하였으며, 공통분의 초기값은 중다상관자승치(squared 
multiple correlation)로 추정하였다. 요인의 해석이 용이하도록 직각회전(varimax)를 사용하였다. 예비검사 참여자를 대상으로 실시한 탐색적 요인분석 결과, 고유치(eigen value)와 스크리 검 사, 누적분산비율을 고려하여 9 개의 요인이 추출되었다(<표 $3>$ 참조). 요인 1 은 교사지지를 측정 하기 위해 개발된 문항들로 이루어져 있는 교사지지 요인으로 확인되었으며, 요인2는 또래지지 를 측정하기 위한 문항들로 이루어진 또래지지 요인으로 구성되었다. 요인3은 학급응집성을 측 정하기 위해 개발한 문항들로 이루어져있으며, 요인4는 또래의 학급폭력허용을 측정하는 문항 들로 이루어졌다. 요인5는 학급규칙을 측정하는 문항들이었고, 요인6은 교사의 학급폭력허용 문 항들로 구성되어 있었다. 요인7은 ‘담임선생님은 따돌림이나 괴롭힘에 대해 관심이 없는 것 같 다','우리 반 친구들은 나에게 관심이 없다'와 같이 담임선생님이나 친구 관계와 관련한 부적 (reverse) 문항 3개로 이루어져 있었으며, 요인8은 '우리 반에는 나를 싫어하는 친구가 있다','우 리 반 친구들은 학급 규칙을 중요하게 생각하지 않는다'의 문항처럼 자신 또는 학급과 관련된 4 개의 부적 문항으로 구성되어 있었다. 이처럼 요인7과 요인8에 부하된 문항 7 개는 특정한 하위 척도를 측정할 수 있는 문항들로 구성되었다기보다 부적인 문항들로 묶여있을 뿐이어서 요인의 의미를 해석하기가 어렵기 때문에 해석 가능성을 고려하여 삭제하였다. 요인 9에는 2문항이 포 함되어 있어 척도로 구성하기에는 적은 문항으로 판단되어 삭제하였다. 탐색적 요인분석 결과 최종적으로 9문항이 삭제한 후, 6 개 요인을 측정하는 35 개 문항을 선정하였다.

<표 3> 학급환경 진단도구 예비문항의 탐색적 요인분석 결과

\begin{tabular}{cccccccccc}
\hline $\begin{array}{c}\text { 문항 } \\
\text { 번호 }\end{array}$ & 1 & 2 & 3 & 4 & 5 & 6 & 7 & 8 & 9 \\
\hline 2 & .728 & .212 & .172 & -.123 & .100 & .084 & -.146 & -.081 & .097 \\
\hline 13 & .721 & .216 & .204 & -.008 & .172 & .093 & .055 & -.068 & -.048 \\
\hline 5 & .710 & .239 & .172 & -.091 & .117 & .128 & -.161 & -.040 & .037 \\
\hline 8 & .656 & .323 & .073 & -.195 & .220 & .177 & -.182 & .022 & -.049 \\
\hline 19 & .563 & .058 & .432 & -.111 & .176 & .270 & -.030 & -.001 & -.037 \\
\hline 10 & .171 & .772 & .147 & -.063 & .216 & .140 & -.103 & -.038 & -.090 \\
\hline 12 & .237 & .767 & .160 & -.011 & .117 & -.003 & .050 & -.059 & -.026 \\
\hline 7 & .154 & .750 & .197 & -.203 & .139 & .096 & -.073 & -.088 & -.149 \\
\hline 4 & .217 & .664 & .239 & -.090 & .213 & .130 & -.070 & -.223 & -.001 \\
\hline 1 & .198 & .625 & .068 & -.053 & .065 & .164 & -.134 & -.159 & .190 \\
\hline 41 & .264 & .176 & .739 & -.099 & .158 & .149 & -.130 & -.139 & -.012 \\
\hline 38 & -.029 & .283 & .697 & -.101 & .183 & .039 & .007 & -.239 & -.123 \\
\hline 28 & .219 & .269 & .659 & -.132 & .196 & .255 & -.252 & -.031 & -.005 \\
\hline 21 & .448 & -.032 & .604 & .089 & -.015 & .106 & -.360 & .072 & .035 \\
\hline 44 & .292 & .084 & .517 & -.130 & .004 & .119 & .144 & -.089 & .152 \\
\hline
\end{tabular}




\begin{tabular}{|c|c|c|c|c|c|c|c|c|c|}
\hline $\begin{array}{l}\text { 문항 } \\
\text { 번호 }\end{array}$ & 1 & 2 & 3 & 4 & 5 & 6 & 7 & 8 & 9 \\
\hline 22 & .453 & .239 & .503 & -.008 & -.009 & .200 & -.214 & -.045 & .067 \\
\hline 35 & .175 & .341 & .472 & -.314 & .195 & .211 & .030 & -.046 & .066 \\
\hline 39 & -.221 & -.040 & .044 & .622 & -.138 & -.146 & .192 & -.013 & .060 \\
\hline 31 & .098 & -.216 & -.241 & .604 & -.160 & .033 & .088 & .195 & -.044 \\
\hline 42 & -.075 & -.187 & -.048 & .552 & -.098 & -.252 & .225 & .099 & .283 \\
\hline 36 & -.273 & -.189 & -.073 & .542 & -.045 & -.155 & .218 & .262 & -.074 \\
\hline 29 & .014 & .035 & .004 & .496 & -.447 & .052 & -.071 & .313 & -.043 \\
\hline 33 & -.056 & .112 & -.226 & .430 & .123 & .016 & .065 & .053 & .306 \\
\hline 26 & .041 & -.109 & -.167 & .422 & .191 & .059 & .275 & .287 & .110 \\
\hline 11 & .233 & .186 & .152 & .068 & .708 & .035 & -.076 & -.098 & -.049 \\
\hline 6 & .030 & .131 & .107 & -.107 & .647 & .213 & -.049 & -.018 & .043 \\
\hline 9 & .242 & .380 & .004 & -.207 & .561 & .233 & -.006 & -.015 & .086 \\
\hline 14 & .330 & .290 & .206 & -.260 & .534 & .004 & .233 & -.191 & -.103 \\
\hline 15 & .439 & .341 & .164 & .059 & .460 & .321 & -.109 & -.083 & -.048 \\
\hline 3 & .355 & .326 & .217 & -.058 & .371 & .148 & -.288 & .018 & .199 \\
\hline 27 & .071 & .201 & .186 & -.066 & .137 & .699 & -.204 & -.037 & -.097 \\
\hline 34 & .030 & .152 & .133 & -.131 & .121 & .649 & -.332 & .018 & .221 \\
\hline 40 & .222 & .095 & .141 & -.024 & .159 & .645 & -.112 & -.076 & -.197 \\
\hline 43 & .354 & -.041 & .123 & -.025 & .113 & .582 & .236 & -.261 & -.082 \\
\hline 25 & .321 & .273 & .341 & -.198 & -.011 & .450 & -.002 & .040 & .020 \\
\hline 30 & -.134 & -.069 & -.066 & .194 & .066 & -.226 & .727 & .205 & .168 \\
\hline 32 & -.151 & -.066 & -.090 & .307 & -.081 & -.124 & .711 & .147 & .096 \\
\hline 24 & -.171 & -.065 & -.124 & .275 & -.266 & -.091 & .502 & .241 & .187 \\
\hline 18 & .020 & -.287 & -.030 & .127 & .024 & -.161 & .319 & .692 & .051 \\
\hline 17 & -.168 & -.021 & -.077 & .373 & -.086 & -.030 & .080 & .686 & -.021 \\
\hline 20 & .012 & -.152 & -.184 & .113 & -.272 & -.080 & .105 & .608 & -.019 \\
\hline 16 & -.419 & -.076 & -.126 & .005 & .066 & .088 & .431 & .446 & .144 \\
\hline 37 & .049 & -.002 & .085 & .094 & .010 & -.064 & .161 & -.032 & .762 \\
\hline 23 & .006 & -.230 & -.025 & .243 & -.016 & -.180 & .323 & .252 & .407 \\
\hline 고유치 & 4.381 & 4.174 & 3.611 & 2.889 & 2.813 & 2.768 & 2.729 & 2.331 & 1.343 \\
\hline $\begin{array}{l}\text { 설명 } \\
\text { 분산 }\end{array}$ & 9.956 & 9.485 & 8.207 & 6.565 & 6.393 & 6.290 & 6.202 & 5.297 & 3.052 \\
\hline $\begin{array}{l}\text { 누적 } \\
\text { 분산 }\end{array}$ & 9.956 & 19.441 & 27.648 & 34.213 & 40.606 & 46.896 & 53.098 & 58.395 & 61.447 \\
\hline
\end{tabular}




\section{2. 본 검사 분석}

1) 구인타당도

예비검사 결과 추출된 35 문항에 대해 문항의 표현 및 의미전달의 적절성 등을 검토하여 문항 을 다시 수정하는 작업을 거쳤다. 학급환경 진단척도의 구인타당도 검증을 위해 본 검사의 참여 자를 대상으로 확인적 요인분석(confirmatory factor analysis)을 실시하였다. 우선 척도가 요인 분석에 적합한지 알아보기 위해서 탐색적 요인분석을 실시하여 $\mathrm{KMO}$ 값과 Barlett 구형성 검증 을 한 결과, $\mathrm{KMO}$ 값이 $.917, \mathrm{Barlett}$ 구형성 검정결과 카이자승값이 5910.384( $p \times .001)$ 로 타당한 것으로 나타났다. 요인수는 6 개 요인이 적합한 것으로 나타났으며, 6 개 요인은 약 $57.2 \%$ 의 설명 력을 갖고 있다. 상관행렬표는 <표 $4>$ 에 제시하였다.

탐색적 요인분석에서는 많은 관찰변인이 적은 수의 요인으로 환원되는 것에 초점을 두지만, 구조방정식의 측정모형에서는 잠재변인이 어떤 관찰변인을 통해 가시적으로 드러나는가에 초 점을 둔다(이기종, 2000). 탐색적 요인분석을 통해 확인된 6개 요인의 상호관련성을 가정한 연구 모형을 설정하고 잠재변인을 측정하고 있는 대표적인 문항 3 개씩을 관찰변인으로 하여, 연구모 형의 구인타당화를 위해 최대우도 추정방법으로 확인적 요인분석을 실시하여 모형의 적합도를 살펴보았다.

<표 4> 학급환경 진단척도의 상관행렬

\begin{tabular}{|c|c|c|c|c|c|c|}
\hline & 또래지지 & $\begin{array}{l}\text { 또래-학급 } \\
\text { 폭력허용 }\end{array}$ & 교사지지 & $\begin{array}{c}\text { 교사-학급 } \\
\text { 폭력허용 }\end{array}$ & 학급규칙 & $\begin{array}{l}\text { 학급 } \\
\text { 응집성 }\end{array}$ \\
\hline 또래지지 & 1 & & & & & \\
\hline $\begin{array}{l}\text { 또래-학급 } \\
\text { 폭력허용 }\end{array}$ & $-.271 * *$ & 1 & & & & \\
\hline 교사지지 & $.504 * *$ & $-.177 * *$ & 1 & & & \\
\hline $\begin{array}{l}\text { 교사-학급 } \\
\text { 폭력허용 }\end{array}$ & $-.412 * *$ & $.286 * *$ & $-.570 * *$ & 1 & & \\
\hline 학급규칙 & $.573 * *$ & $-.366 * *$ & $.646 * *$ & $-.551 * *$ & 1 & \\
\hline $\begin{array}{l}\text { 학급 } \\
\text { 응집성 }\end{array}$ & $.480 * *$ & $-.288 * *$ & $.558 * *$ & $-.583 * *$ & $.517 * *$ & 1 \\
\hline
\end{tabular}

${ }^{* *} p<.01,{ }^{* * *} p<.001$

RMSEA(Root Mean Square Error of Approximation)는 .10이하이면 적합도가 양호하고, CFI(Comparative Fit Index,) IFI(Incremental Fix Index), TLI(Tucker-Lewis Index)는 1에 가까울 수록 좋은 적합도, .90이상이면 양호한 적합도로 판명할 수 있다(Steiger, 1990). 연구모형의 적 
합도 지수를 살펴본 결과, 연구자가 가정하는 모형의 적합도 향상 정도를 비율로 표시한 CFI, $\mathrm{IFI}, \mathrm{TLI}$ 가 각각 $.935, .937, .908$ 로 양호한 적합도를 보이고 있으며, 추정오차의 평균으로서 관찰 값과 모델 분산공분산 행렬의 적합도 정도를 알려주는 RMSEA가 .056으로 양호하게 나타났다. 적합도 지수 및 모형의 표준화요인계수는 <표 5>, [그림 1]에 제시하였다.

<표 5> 적합도 지수

\begin{tabular}{|c|c|c|c|c|c|c|c|}
\hline & $x^{2}$ & $d f$ & $p$ & $\mathrm{CFI}$ & IFI & TLI & RMSEA \\
\hline 연구모형 & 267.620 & 120 & .000 & .935 & .937 & .908 & .056 \\
\hline
\end{tabular}

2) 기초통계 분석치와 신뢰도 분석

최종적으로 확인된 6 요인 35 문항으로 구성된 학급환경 진단도구의 최소값, 최대값, 평균 및 표준편차와 문항수, 첨도와 왜도, 신뢰도계수를 <표 6>에 제시하였다. 6개 요인에 대한 문항내 적 합치도를 산출한 결과, .705에서 .864 사이의 대체로 양호한 신뢰도를 보였다.

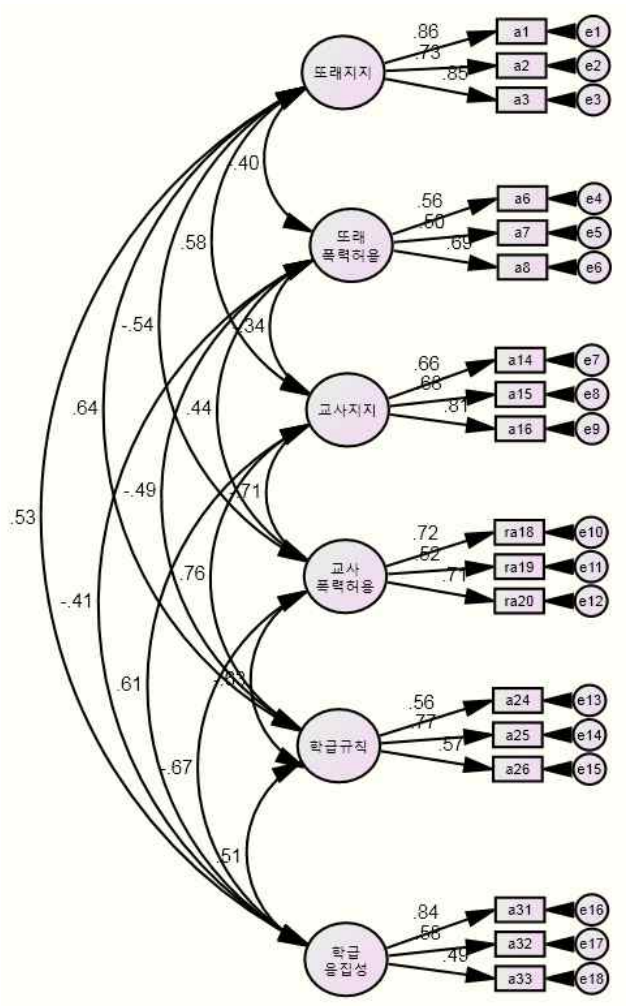

[그림 1] 연구 모형의 표준화 요인계수 
<표 6> 학급환경 하위척도의 문항 수 및 기초통계 분석치와 문항내적합치도

\begin{tabular}{cccccccccc}
\hline & $\begin{array}{c}\text { 본 검사 } \\
\text { 문항 수 }\end{array}$ & 최소값 & 최대값 & 평균 & 표준편차 & 왜도 & 첨도 & $\begin{array}{c}\text { Cronbach's } \\
\alpha\end{array}$ & 예비문항번호 \\
\hline 또래지지 & 5 & 5 & 22 & 16.07 & 3.14 & -.718 & .325 & .864 & $10,12,7,4,1$ \\
\hline $\begin{array}{c}\text { 또래- } \\
\text { 학급폭력허용 }\end{array}$ & 7 & 7 & 35 & 18.72 & 4.54 & .057 & .354 & .709 & $\begin{array}{c}39,31,42,36, \\
29,33,26\end{array}$ \\
\hline 교사지지 & 5 & 9 & 25 & 18.84 & 3.59 & .032 & -.662 & .846 & $2,13,5,8,19$ \\
\hline $\begin{array}{c}\text { 교사- } \\
\text { 학급폭력허용 }\end{array}$ & 5 & 5 & 17 & 10.40 & 3.12 & -.029 & -.983 & .705 & $\begin{array}{c}.72,34,40,43, \\
25\end{array}$ \\
\hline 학급규칙 & 6 & 10 & 30 & 22.31 & 4.16 & -.010 & -.454 & .795 & $\begin{array}{c}11,6,9,14, \\
15,3\end{array}$ \\
\hline 학급응집성 & 7 & 10 & 35 & 25.60 & 5.47 & -.191 & -.470 & .854 & $\begin{array}{c}.71,38,28,21, \\
44,22,35\end{array}$ \\
\hline
\end{tabular}

3) 공인타당도

학급환경 진단도구의 준거관련 타당도를 검증하기 위하여 학교폭력 가피해 경험척도와의 상 관분석을 실시하였다. 학교폭력 피해경험과 학급환경의 하위변인들과의 상관관계를 살펴보면, 또래지지(-.223, $p<.01)$, 학급응집성(-.193, $p<.01)$, 학급규칙(-.161, $p<.01)$ 이 유의한 부적 상관을 보 이고 있으며, 또래폭력허용과는 .262( $p<.01)$ 의 유의한 정적 상관을 보이고 있다. 학교폭력 가해경 험과 학급환경의 하위변인들과의 상관관계를 살펴보면, 학급규칙(-.158, $p<.01)$, 교사지지(-.131, $p<.01)$, 학급응집성(-.120, $p<.05)$ 과 유의한 부적 상관을 보였으며, 또래폭력허용과는 .152( $p<.01)$ 의 유의한 정적 상관을 보이고 있었다. 반면, 학교폭력 피해경험과 교사지지, 교사폭력허용 및 가해경험과 또래지지, 교사폭력허용 간의 상관은 유의하지 않았다.

또한 본 연구에서 개발한 학급환경 진단척도와 유사한 기존 척도인 학급풍토(MCI) 및 사회적 지지척도(SSAS)와의 상관을 분석하여 공인타당도 검증을 하였다. 학급풍토(MCI)의 하위 척도인 갈등과 응집성 모두 본 연구에서 개발한 척도의 하위요인들과 유의한 상관관계를 보였다. 사회 적지지척도(SSAS)의 또래지지와 교사지지 척도 모두 본 연구에서 개발한 학급환경 진단척도와 유의한 상관관계가 있는 것으로 나타났다. 구체적인 상관계수는 <표 $7>$ 에 제시되어 있다. 
<표 7> 학급환경 진단척도와 학교폭력 가피해 경험, 학급풍토, 사회적지지 간 상관관계

\begin{tabular}{ccccccc}
\hline & \multicolumn{2}{c}{ 가 ·피해 경험 } & \multicolumn{2}{c}{ 학급풍토 } & \multicolumn{2}{c}{ 사회적지지 } \\
\cline { 2 - 7 } & $\begin{array}{c}\text { 피해 } \\
\text { 경험 }\end{array}$ & $\begin{array}{c}\text { 가해 } \\
\text { 경험 }\end{array}$ & 갈등 & 응집성 & 또래지지 & 교사지지 \\
\hline 또래지지 & $-.223 * *$ & -.039 & $-.174 * *$ & $.449 * *$ & $.726 * *$ & $.397 * *$ \\
\hline 또래-학급폭력허용 & $.262 * *$ & $.152 * *$ & $.420 * *$ & $-.433 * *$ & $-.343 * *$ & $-.209 * *$ \\
\hline 교사지지 & -.027 & $-.131 * *$ & $-.131 * *$ & $.337 * *$ & $.426 * *$ & $.725 * *$ \\
\hline 교사-학급폭력허용 & .043 & .086 & $.109 *$ & $-.363 * *$ & $-.459 * *$ & $-.614 * *$ \\
\hline 학급규칙 & $-.161 * *$ & $-.158 * *$ & $-.349 * *$ & $.401 * *$ & $.523 * *$ & $.505 * *$ \\
\hline 학급응집성 & $-.193 * *$ & $-.120 *$ & $-.284 * *$ & $.543 * *$ & $.589 * *$ & $.575 * *$ \\
\hline
\end{tabular}

${ }^{*} p<.05,{ }^{* *} p<.01,{ }^{* * *} p<.001$

\section{$\mathrm{V}$. 논의 및 결론}

학교는 학생들이 인류의 위대한 지적, 상상적, 도덕적, 정서적 유산에 입문하고 이를 상속받는 곳이며, 살아있는 유산인 교사와 학습자 간에 인격적 접촉이 이루어지는 곳이다(Oakeshott, 1972). 그런데 학교에 폭력이 만연하다는 것은 이러한 교육의 본래적 의미가 실천되지 못하고 있다는 것, 다시 말해서 학생들이 인간다운 삶에 입문하지 못한다는 것을 의미한다고 볼 수 있다 (유재봉, 2012). 따라서 학교에서 발생하는 폭력은 시급하게 해결해야 할 과제이며, 이를 위한 가장 최선의 방법은 학교폭력을 예방하는 일일 것이다.

학교폭력 문제가 발생한 이후에 대처하는 반응적 접근(reactive approach)보다는 문제가 발생 하기 이전에 예방과 조기개입에 초점을 둔 선제적 접근(proactive approach)이 중요하며(오인수, 2010), 특히 학교폭력을 예방하기 위해서는 피해학생과 가해학생 등 학생 개인만을 다루는 접근 보다는 학급차원의 접근이 필요하다(서기연, 유형근, 권순영, 2011; 오해영, 김호영, 2005; 장미향, 성한기, 2007; Ttofi \& Farrington, 2011).

본 연구는 학교폭력을 예방하기 위해서는 학교폭력이 주로 발생하는 교실, 즉 학급차원의 접 근이 필요하며, 학교폭력에 영향을 미치는 미시체계인 또래변인, 교사변인 등의 학급환경을 진 단하고 개입하는 것이 중요하다는 문제의식을 가지고 학교폭력 예방을 위한 학급환경 진단도구 를 개발하였다. 학교폭력을 예방하기 위한 학급환경 진단척도를 구성하기 위해 관련 연구들을 분석한 결과, 또래지지(김미경, 강문희, 2006; 한남식, 어주경, 2012), 또래폭력허용(김미영, 2007; 최운선, 2005), 교사지지(박영신, 김의철, 2001; 장미향, 성한기, 2007; Orpinas \& Horne, 2006), 교사폭력허용(김경집, 2005; 김미영, 2007; 정진성, 2009; Harootunuan \& Apter, 1993), 학급규칙 
(박주형, 정성수, 2012; 이상균, 1999), 학급응집성(이훈구 등, 2000; 김미영, 2007)을 추출하여 하 위척도를 구성하고 문항을 개발하였다.

예비검사 및 본 검사를 통해, 최종적으로 구성한 학급환경 진단도구의 하위척도는 또래지지, 또래폭력허용, 교사지지, 교사폭력허용, 학급규칙, 학급응집성 등 총 6개요인 35문항이며 타당화 를 위해 구인타당도 및 공인타당도를 분석한 결과는 다음과 같다.

첫째, 학급환경 진단척도의 구인타당도를 검증하기 위해 확인적 요인분석을 실시한 결과 또 래지지, 또래폭력허용, 교사지지, 교사폭력허용, 학급규칙, 학급응집성 6개 요인의 상호관련성을 가정한 연구모형의 적합도 지수(CFI, IFI, TLI, RMSEA)가 양호한 것으로 나타났다. 즉, 학급환경 진단 척도로서 6 개의 하위요인이 상호관련성을 가지고 있다는 타당성을 확보하였다.

둘째, 학급환경 진단척도의 준거관련 타당도를 검증하기 위해 학교폭력 가해경험 및 피해경 험 척도와의 상관분석을 실시한 결과, 학교폭력 피해경험은 또래지지, 학급규칙, 학급응집성, 또 래폭력허용과 유의한 상관이 나타났으며, 학교폭력 가해경험은 또래폭력허용, 교사지지, 학급규 칙, 학급응집성과 유의한 상관이 나타났다. 이는 또래지지와 학교폭력 피해경험의 부적 상관(김 혜원, 2001; 이혜경, 김미경, 강문희, 2006; 한남식, 어주경, 2012), 교사지지와 학교폭력 가해경험 의 부적 상관(황혜원, 신정이, 박현순, 2006), 또래폭력허용과 학교폭력 가.피해경험의 정적 상관 (김미영, 2007; 최운선, 2005), 학급규칙 및 학급응집성과 학교폭력 가·피해경험과의 부적 상관 (김미영, 2007; 박주형, 정성수, 2012)을 보고한 선행연구들과 일치하는 결과이다. 그러나 교사지 지의 경우, 가 - 피해 경험 중 가해 경험과는 유의한 상관이 나타났지만, 피해 경험과는 유의하지 않은 것으로 나타났다. 또한 교사-학급폭력 허용은 가 - 피해 경험 모두 유의하지 않은 것으로 나타났다. 그러나 많은 선행연구(김경집, 2005; 김은영, 2008, 오인수, 이승연, 이주연, 2013; 신성 자, 권신영, 2013; 정진성, 2009)에서 교사와 학생 간의 관계, 학교폭력에 대한 교사의 인식과 같 은 교사의 태도가 학교폭력의 보호요인으로 보고하고 있다. 추후연구에서 교사변인과 학교폭력 관련 변인과의 관련성을 규명하여 교사변인의 중요성을 확인할 필요가 있을 것이다.

셋째, 학급환경 진단도구의 공인타당도 검증을 위해 학급환경 진단도구와 유사한 기존 척도 인 학급풍토 척도와 사회적지지 척도와의 상관관계를 분석한 결과, 학급환경 진단도구의 모든 하위 척도와 유의한 상관이 나타났다. 특히, 학급환경 진단도구의 학급응집성과 학급풍토(MCI) 척도의 응집성, 학급환경 진단도구의 또래폭력허용과 학급풍토 $(\mathrm{MCI})$ 척도의 갈등, 학급환경 진 단도구의 또래지지와 교사지지는 사회적지지척도(SSAS)의 또래지지와 교사지지와 각각 유의한 정적 상관을 보이고 있다.

이상에서와 같이 본 연구에서 개발한 학급환경 진단척도는 학교폭력 예방을 위한 학급환경을 진단하기 위한 도구로써 구인타당도와 공인타당도를 확보하였다. 따라서 단위학교 및 학급의 담 임교사는 학교폭력을 예방하기 위한 학급관리 및 학급환경 조성을 위해 본 척도를 활용하여 기 
초적인 정보를 얻을 수 있을 것이다. 학교폭력을 예방하기 위해서는 학급의 분위기와 같은 학급 차원의 사회 환경을 변화시키는 것이 근본적이고 효율적인 방법이다(서기연, 유형근, 권순영, 2011; 장미향, 성한기, 2007). 학급환경 진단척도는 첫째, 학급의 또래지지 및 교사지지 진단을 통해 학급에서의 또래관계 및 교사와 학생 간의 관계를 파악하고 이에 대한 적절한 개입을 할 수 있다. 즉, 교사는 학급에서의 폭력을 예방하기 위해 학생과 학생, 학생과 교사가 상호존중하 고 지지하는 환경을 조성함으로써 또래 괴롭힘 및 학교폭력을 감소시킬 수 있는 것이다(Orpinas \& Horne, 2006). 둘째, 학급의 폭력허용도, 학급규칙에 대한 학생들의 인식, 학급응집성 등의 학 급 분위기 및 학급문화에 대한 정보를 제공하기 때문에 교사는 이를 활용하여 학급차원의 환경 및 문화를 변화시킬 수 있다. 예를 들어, 교사는 학급에서 또래 간에 폭력을 허용하는 문화가 조성되어 있는지를 확인할 수 있으며 이를 개선하기 위한 방안을 세울 수 있을 것이다. 학급의 폭력허용적인 문화는 교사가 폭력에 대해 관심을 가지고 있으며 또래괴롭힘 등의 폭력을 절대 허용하지 않겠다는 태도를 보이는 등의 노력으로 변화될 수 있기 때문이다(김경집, 2005; 정진 성, 2009). 또한 학생들이 폭력에 대한 학급규칙이 일관적이고 공정하게 적용된다고 인식할 수 있도록 학급규칙 제정 시, 학생들을 적극적으로 참여시키고 학급규칙의 공정한 적용을 위해 학 급을 관리하는 등의 개입을 통해 학급문화를 조성할 수 있을 것이다.

본 학급환경 진단척도는 학교폭력을 예방하기 위한 개인적 차원에서의 접근이 아닌 학급 차 원에서 접근하였으며, 학교폭력이 발생하는 최소 단위인 학급에서 교사가 학급환경을 정확하게 진단하여 학교폭력 예방을 위한 학급환경을 조성하는데 활용할 수 있도록 개발하였다는 점에서 의의가 있다.

본 연구에서 개발한 학교환경 진단척도는 초등학교 고학년(5-6학년)과 중학교(1-2학년) 학생 을 대상으로 타당화 된 것으로 초등학교 고학년 학급과 중학교 학급에서 학교폭력예방을 위한 학급환경을 진단하기 위해 활용 가능하다. 그러나 학교급별, 남녀합반 및 남학생 학급, 여학생 학급별로 맞춤형 학급환경 조성을 위해 활용되기 위해서는 향후 초등학교 고학년과 중학교의 학교급별, 남학생과 여학생의 성별에 따른 다집단 분석을 통한 구인타당도를 확보할 필요가 있 겠다. 또한 최근 학교폭력의 저연령화 추세 및 학교폭력 최초경험이 초등학교 저학년이며, 학교 폭력예방교육의 효과가 가장 크게 나타난 학교급 또한 초등학교 저학년임(이희현, 2014)을 반영 하여, 초등학교 저학년 학급에서 활용 가능한 학급환경 진단도구를 개발할 필요가 있겠다. 


\section{참고문헌}

강진령(2011). 집단상담의 실제. 서울: 학지사.

교육부(2014). 2014년 1차 학교폭력 실태조사 결과. 보도자료.

김경집(2005). 초기 청소년의 또래폭력에 영향을 미치는 요인: 학교환경과 학구를 중심으로. 한

국청소년연구, 16(1), 421-448.

김미경, 강문희(2006). 사회적 지지와 귀인성향이 또래괴롭힘 가해, 피해에 미치는 영향. 심리치

료: 다학제적 접근, 6(2), 1-17.

김미영(2007). 학교체계가 중학생의 학교폭력에 미치는 영향. 한국청소년연구, 18(2), 287-314. 김순혜(2012). 초등학교 학교폭력 피해아동의 위험요인과 보호요인 분석. 아동교육, 21(3), 5-17. 김은영(2008). 학교분위기가 중학생의 또래폭력 피해경험에 미치는 영향. 한국아동복지학, 26 ,

87-111.

김준호, 박정선, 김은경(1996). 학교주변 폭력의 실태와 대책. 서울: 한국형사정책연구원. 남영옥, 한상철(2007). 청소년폭력 예방을 위한 보호요인들의 영향력 탐색. 청소년상담연구, 15(1), 77-89.

도기봉(2007). 학교폭력 가해행동에 영향을 미치는 요인에 관한 연구. 박사학위논문, 대구대학교. 박성희(2005). 담임이 이끌어가는 학급상담. 서울: 학지사.

박영신, 김의철(2001). 청소년 학교폭력행동과 환경 및 심리적 특성의 관계: 위탁청소년과 중고 등학생을 중심으로. 교육심리연구, 15(2), 25-52.

박종효(2013). 또래 괴롭힘에 영향을 미치는 학생 및 학교 특성 탐색: BMI와 학교공시지표 중심 으로. 아시 아교육연구, 14(1), 69-95.

박주형, 정성수(2012). 고등학교 학생의 학교폭력에 대한 인식과 학교의 영향 요인 탐색. 교육행 정학연구, 30(3), 1-19.

서기연, 유형군, 권순영(2011). 초등학교 고학년을 위한 또래지지 중심 집단따돌림 예방 프로그

램 개발. 아동교육, 20(2), 131-146.

성지희, 정문자(2007). 학교폭력 피해아동의 학교적응과 보호요인. 아동학회지, 28(5), 1-18. 신성자(2005). 학교폭력, 가해, 피해 그리고 대응관련 요인. 사회과학, 17, 111-142. 신성자, 권신영(2013). 학교폭력에 대한 교사의 개입수준과 관련요인들의 10 년의 변화추이에 대 한 분석. 학교사회복지, 26, 177-207.

윤경철, 강명숙(2012). 교사설문조사결과분석. 학교폭력 및 학교문화에 대한 학부모-교사인식조 사연구(pp.35-64). 서울: 한국청소년정책연구원. 
오인수, 이승연, 이주연(2013). 학교폭력 가해·피해 학생을 위한 교육적 개입에 관한 연구. 이 화여자대학교 학교폭력예방연구소.

오인수(2010). 집단따돌림 해결을 위한 전문상담교사의 전학교 접근. 상담학연구, 11(1), 303-316.

오해영, 김호영(2005). 중학생 집단따돌림 예방 프로그램의 효과에 관한 연구. 미래청소년학회 지, 2(1), 47-59.

유재봉(2012). 학교폭력의 현상과 그 대책에 대한 철학적 검토. 교육철학연구, 34(3), 87-106. 이기종(2000). 구조방정식모형. 서울: 교육과학사.

이상균(1999). 학교에서의 또래폭력에 영향을 미치는 요인. 박사학위논문, 서울대학교.

이상균(2005). 청소년의 또래폭력 가해경험에 대한 생태체계적 영향 요인. 한국아동복지학, 19, 142-170.

이수경, 오인수(2012). 사이버 괴롭힘과 오프라인 괴롭힘에 영향을 미치는 요인 비교 분석. 아시 아교육연구, 13(2), 137-161.

이승하(2012). 학교폭력의 현황과 실태, 원인분석: 비교문화적으로 본 한국 학교폭력의 발생현황 과 특징. 한국교원교육학회 학술대회 발표자료집, 1-18.

이은정(1997). 학급환경 척도 타당화에 대한 예비연구. 석사학위논문, 연세대학교. 이은희, 공수자, 이정숙(2004). 청소년들의 가정, 학교, 지역의 심리사회적 환경과 학교폭력과의 관계: 분노조절과 비행친구 접촉의 매개효과. 한국심리학회지: 상담 및 심리치료, 16(1), 123-145.

이점형(2013). 정서지능, 학급풍토 및 사히적 지지가 교우관계 질에 미치는 영향: 영재학생과 일 반학생의 비교를 중심으로. 박사학위논문, 경북대학교.

이정윤(2014). 학급차원의 학교폭력예방, 청소년폭력예방재단 학교폭력문제연구소(편)(2014) 학 교폭력 예방의 이론과 실제, pp. 207-232.

이춘재, 곽금주(2000). 집단 따돌림 경험유형에 따른 자기개념과 사회적지지. 한국심리학회지: 발달, 13(1), 65-80.

이훈구, 권준모, 곽금주, 조성호, 전우영, 이혜주(2000). 학급내 부정적 행동과 응집력과의 관계: 왕따, 학내폭력, 수업저해행동을 중심으로. 2000년도 한국심리학회 연차학술발표대 회 논문집.

이혜경, 김혜원(2001). 초등학생들의 집단괴롭힘 가해행동과 피해행동에 대한 사회적, 심리적 예 측변인들: 학년과 성별을 중심으로. 한국심리학회지: 사회 및 성격, $15(1), 117-138$. 이희현(2014). 어울림프로그램의 적용 및 효과. 2014 한국인간발달학회 추계학술대회 자료집, 35-60.

장명배(2008). 학급 내 학교폭력 조기 감지 및 상담방법. 문용린 외 공저(2008). 학교폭력 예방과 
상담(pp.319-333). 서울: 학지사.

장미향, 성한기(2007). 집단따돌림 피해 및 가해경험과 사회정체성 및 사회지지의 관계. 한국심 리학회, 21(1), 77-87.

정규석(2006). 초등학생과 중학생의 학교폭력 영향요인 비교. 사회과학연구, 24(4), 323-338. 정진성(2009). 학교폭력의 원인에 대한 연구: 지역사회의 영향을 중심으로. 한국공안행정학회, 18(2), 365-394.

최운선(2005). 학교폭력 관련변인에 관한 메타분석. 한국가족복지학, 10(2), 95-111.

한남식, 어주경(2012). 중학생의 대인관계 성향, 또래 괴롭힘, 사회적 지지와 사회적 불안과의 관 계. 생애학회지, 2(1), 71-84.

황혜원, 신정이, 박현순(2006). 초기 청소년의 학교폭력에 대한 생태체계적 요인들 간의 경로분 석. 아동권리연구, 10(4), 497-526.

Astor, R. A., Meyer, H. A., \& Behre, W. J. (1999). Unowned places and times: Maps and interviews about violence in high school. American Education Research Journal, 36(1), 3-42.

Benbenishty, R., Astor, R. A., Zeira, A., \& Vinokur, A. (2002). Perceptions of violence and fear of school attendance among junior high school students' in Israel. Social Work Research, 26(2), 71-87.

Dubow, E. F., \& Ullman, D. G. (1989). Assessing social support in elementary school children: The survey of children's social support. Journal of Clinical Child Psychology, 18(1), $52-64$.

Dwyer, K. P., Osher, D., \& Hoffman, C. C. (2000). Creating responsive schools: Contextualizing early warning, timely response. Exceptional Children, 66(3), 347-363.

Furlong M., \& Morrison. G. (2000). The school in school violence: Definition and facts. Journal of Emotional and Behavior Disorder, 8(2), 71-82.

Furlong, M. J., Grief, J. L., Bates, M. P., Whipple, A. D., Jimenez, T. C., \& Morrison, R. (2005). Development of the California School Climate and Safety Survey-Short Form. Psychology in the Schools, 42(2), 137-149.

Gottfredson, G. D., Gottfredson, D. C., Payne, A. A., \& Gottfredson, N. C. (2005). School climate predictors of school disorder: Results from a national study of delinquency prevention in schools. Journal of Research in Crime \& Delinquency, 42(2), 412-444.

Guerra, N. G., Williams, K. R. \& Sadek, S. (2011). Understanding bullying and victimization during childhood and adolescence: A mixed methods study. Child Development, 82(1), 295-310. 
Harootunian, B., and S. J. Apter. (1993). Violence in school. In A. P. Godlstein(Ed.), Youth violence(pp. 120-139). Elmsford, NY: Pergamon press.

Hein, K. (2004). Preventing aggression in the classroom: A case study of extraordinary teachers. Unpublished doctoral dissertation, University of Georgia.

Hyman, I. A., \& Perone, D. C. (1998). The other side of school violence: Educator policies and practices that may contribute to student misbehavior. Journal of School Psychology, $36(1), 7-27$.

Kasen, S., Berenson, K., Cohen, P., \& Johnson, J. G. (2004). The effects of school climate on changes in aggressive and other behaviors related to bullying. In D. L. Espelage \& S. Swearer (Eds.), Bullying in American Schools (pp. 187-210). Mahwah, NJ: Erlbaum.

Kasen, S., Cohen, P., \& Brooks, J. S. (1998). Adolescent school experiences and dropout, adolescent pregnancy, and young adult deviant behavior. Journal of Adolescent Research, 13(1), 49-72.

Oakeshott, M. (1972). Education: The engagement and its frustration. In T. Fuller(Ed.)(2001), The voice of liberal learning (pp.62-104). Indiana: Liberty Fund.

Olweus, D. (1994). Annotation: Bullying at school: Basic facts and effects of a school based intervention program. Journal of Child Psychology and Psychiatry, 35(7), 1171-1190.

Orpinas, P., \& Horne, A. M. (2006). Bullying Prevention: Creating a positive school climate and developing social competence. 한유경 외 역(2013). 괴롭힘 예방: 행복한 학교문화 조성과 사회적 역량 개발. 경기: 아카데미프레스.

Pozzoli, T., Gini, G., \& Vieno, A. (2012). The role of individual correlates and class norms in defending and passive bystanding behavior in bullying: A multilevel analysis. Child Development, 83(6), 1917-1931.

Rigby, K. (2000). Effects of peer victimization in schools and perceived social support on adolescent well-being. Journal of adolescence, 23(1), 57-68.

Rutter, M., Maughan, B., Mortimore, P., Ouston, J., \& Smith, A. (1979). Fifteen thousand hours: Secondary schools and their effects on children. Cambridge, MA: Harvard University Press,

Ryan, A. M., \& Patrick, H. (2001). The classroom social environment and cjanges in adolescents' motivation and engagement during middle school. American Educational Research Journal, 38(2), 437-760.

Schmuck, R. A., \& Schmuck, P. A. (1992). Group processes in the classroom. 김경식 역(2000). 학급의 사회심리학: 협력학습 조성을 위한 기초이론과 실제. 서울: 원미사. 
Steiger, J. H. (1990). Structural model evaluation and modification: An interval estimation approach. Multivariate Behavioral Research, 25(2), 173-180.

Ttofi, M, M., \& Farrington, D. P. (2011). Effectiveness of school-based programs to reduce bullying: A systematic and meta-analytic review. Journal of Experimental Criminology, 71), 27-56.

Trickett, E. J., \& Moos, R. H. (1973). The social environment of junior high school classroom, Journal of Educational Psychology, 65(1), 93-102.

Yablon, Y. B. (2012). Student-teacher relationships and students, willingness to seek help for school violence. Journal of Social and Personal Relationships, 278), 1110-1123.

You, S., Furlong, M. J., Felix, E., Sharkey, J. D., Tanigawa, D., \& Green, J. G. (2008). Relations among school connectedness, hope, life satisfaction, and bully victimization. Psychology in the Schools, 45(5), 446-460.

http://www.lawnb.com/lawinfo/link_view.asp?cid=86726D6D84B1499490D1B1B3B19D2B5B | L, (검색일, 2014.9.30.)

\footnotetext{
* 논문접수 2014년 11월 4일 / 1차 심사 2014년 11월 24일 / 게재승인 2014년 12월 15일

* 이숙정: 숙명여자대학교 대학원에서 교육심리 전공으로 박사학위를 취득하였으며, University of Washington(Seattle) 에서 Post-doc, 동국대(경주) 조교수를 거쳐 현재 숙명여대 리더십교양교육원 부교수로 재직 중이다. 주 관심사는 역량교육, 환경교육, 학교환경 등이다.

*E-mail: leesjeong@sm.ac.kr

* 박소연: 숙명여자대학교 대학원에서 교육심리 전공으로 박사학위를 취득하였으며, 한국행동과학연구소 검사연구본부장을 거쳐 현재 숙명여자대학교 리더십교양교육원 겸임교수 및 (주마인드업 대표로 재직 중이다. 주 관심사는 대학생 역량 및 진로, 동기, 심리검사 개발 등이다.

*E-mail: psychitest@naver.com
}

* 이희현: 숙명여자대학교 대학원에서 교육심리전공으로 박사학위를 취득하였으며, 현재 한국교육개발원 연구위원으로 재직 중이다. 주 관심사는 학교폭력예방교육, 인성교육, 정서 및 사회성 등이다.

*E-mail: hyun@kedi.re.kr

* 유지현: 숙명여자대학교 대학원에서 교육심리 전공으로 박사학위를 취득하였으며, 현재 선문대학교 교수학습혁신센터 조교수로 재직 중이다. 주 관심사는 역량교육, 정서 및 사회성 등이다.

*E-mail: edupsy0502@sunmoon.ac.kr 


\title{
Abstract
}

\section{The Development of a Scale to Measure of Class Environmental for School Violence Prevention in Korea}

\author{
Lee, Sook-jeong* \\ Park, So Yeun** \\ Lee, Hee Hyun ${ }^{\star * *}$ \\ Yu, Ji Hyun ${ }^{* \star * *}$
}

The purpose of this study was to develop of a valid and reliable scale aiming to measure the class environmental for school violence prevention of students attending grades $5^{\text {th }}$ to $8^{\text {th }}$. The literature and instruments related to class environment and school violence studies were examined. As a result of the examinations, a comprehensive item pool was created and submitted to subject area experts for the content validity. Items in draft scale prepared as 44 negative and positive statements. Two sets of samples (293 and 396 students in Korea) served to explore and confirm the constructs of the class environmental scale for school violence prevention proposed by this study. In principal components analysis for the sample $(n=293)$, the scale of 34 -items factored into 6 sub-scales. A confirmatory factor analysis $(n=396)$ showed that the six-factor model was valid for the sample (RMSEA=.056, TLI=.908, CFI=.935, IFI=.937). Internal consistency reliability, factorial validity, and concurrent validity were satisfactory in the case of the Korean students. The study found that the psychometric properties of the class environmental scale for school violence prevention are acceptable and suitable for use. Implications and limitations of this study were discussed.

Key words: Class environment, School violence, Violence prevention, Scale development

* First author, Sookmyung Women's University

** Corresponding author, Sookmyung Women's University

*** Korean Educational Development Institution

**** Sunmoon University 


\section{<부록> 학교폭력 예방을 위한 학급환경 진단도구 최종 문항}

\begin{tabular}{|c|c|}
\hline 척 도 & 문 \\
\hline \multirow{5}{*}{ 또래지지 } & 우리 반에는 나를 이해해 주는 친구가 있다. \\
\hline & 우리 반에는 내 고민을 털어놓고 이야기할 친구가 있다. \\
\hline & 내가 어려울 때 나를 도와줄 수 있는 친구가 있다. \\
\hline & 우리 반 친구들은 내 생각이나 말을 잘 들어준다. \\
\hline & 우리 반에는 나를 좋아하는 친구가 있다. \\
\hline \multirow{7}{*}{$\begin{array}{c}\text { 또래- } \\
\text { 학급폭력 } \\
\text { 허용 }\end{array}$} & 우리 반 친구들은 서로 싸울 경우, 선생님께 알리지 않는다. \\
\hline & 우리 반 친구들은 서로 놀리거나 헐뜯는다. \\
\hline & 우리 반 친구들은 반에서 따돌림이나 괴롭힘을 당하는 아이가 있을 경우, 모른 체 한다. \\
\hline & 우리 반 친구들은 반에서 누가 따돌림이나 괴롭힘을 당하는지 관심이 없다. \\
\hline & 우리 반 친구들은 욕을 자주 사용한다. \\
\hline & 우리 반 친구들은 따돌림을 당하는 아이는 그럴만한 이유가 있다고 생각한다. \\
\hline & 우리 반 친구들은 싸움을 피하는 아이를 비겁하다고 생각한다. \\
\hline \multirow{5}{*}{ 교사지지 } & 나는 담임 선생님과 가깝게 지낸다. \\
\hline & 담임 선생님께 내 고민을 털어놓고 이야기할 수 있다. \\
\hline & 담임 선생님은 나에게 관심이 많다. \\
\hline & 담임 선생님은 내가 도움을 요청하면 잘 도와주신다. \\
\hline & 나는 담임 선생님을 만나면 기분이 좋다. \\
\hline \multirow{5}{*}{$\begin{array}{c}\text { 교사- } \\
\text { 학급폭력 } \\
\text { 허용 }\end{array}$} & 담임 선생님은 우리 반에서 따돌림이나 괴롭힘이 있을 때, 주의를 주신다.* \\
\hline & 담임 선생님은 우리 반에서 따돌림이나 괴롭힘이 일어나지 않아야 한다고 말씀하신다.* \\
\hline & 담임 선생님은 괴롭힘을 당하는 아이가 있으면 즉시 보호해 주신다.* \\
\hline & 담임 선생님은 우리 반에서 누가 친구들을 괴롭히는지 알고 계신다.* \\
\hline & 담임 선생님은 우리 반에서 괴롭힘이 일어나지 않도록 노력하신다.* \\
\hline \multirow{6}{*}{ 학급규칙 } & 학급 규칙은 학급 회의를 통해 우리가 결정한다. \\
\hline & 우리 반에는 따돌림이나 괴롭히는 행동에 대한 분명한 규칙이 있다. \\
\hline & 우리 반에서 발생한 문제들은 학급 규칙에 따라 처리된다. \\
\hline & 우리 반 학생들은 학급 규칙을 잘 지킨다. \\
\hline & 우리가 만든 학급 규칙을 담임 선생님께서 존중해 주신다. \\
\hline & 우리 반의 학급 규칙은 누구에게나 공정하다. \\
\hline \multirow{7}{*}{$\begin{array}{l}\text { 학급 } \\
\text { 응집성 }\end{array}$} & 나는 우리 반에 있는 것이 행복하다. \\
\hline & 내년에도 우리 반 친구들이 같은 반이 되었으면 좋겠다. \\
\hline & 나는 우리 반에 속해 있는 것이 자랑스럽다. \\
\hline & 내년에도 우리 담임 선생님과 같은 반이 되면 좋겠다. \\
\hline & 다른 반 친구들은 우리 반을 부러워 한다. \\
\hline & 우리 반은 담임 선생님과 친하게 지낸다. \\
\hline & 우리 반은 단합이 잘 된다. \\
\hline
\end{tabular}

